Academy of Management Proceedings

proceedings.aom.org

doi: 10.5465/AMBPP.2014.15565abstract

ACAD MANAGE PROC January 20142014 (Meeting Abstract Supplement) 15565

Social Issues in Management

\title{
Corporate social irresponsibility and audience support: Lessons from the Parmalat scandal
}

\author{
Arabella Mocciaro Li Destri
}

\section{Anna Mina}

\section{Pasquale Massimo Picone}

Author Affiliations

\begin{abstract}
Audience decisions regarding whether to continue to support a corporation after it has been perceived as culpable for socially irresponsible behaviour is "coin of the realm" in selecting which firms (or which parts of a firm) will be able to survive a CSI- scandal. This paper analyses the main dimensions underlying post-CSI audience support decisions. Our empirical setting is an embedded polar case of audience support following a severe CSI scandal. Though we apply the framework developed in the nascent stream of attribution theory in CSI to comprehend the subjective processes underlying audience reactions, this study adds a number of dimensions to those already included in attribution studies. In particular, two dimensions of legitimacy played a key role: moral and market legitimacy. The capacity to manage the interplay between these two dimensions emerged as a key factor underlying audience support. Finally, possessing a sound source of competitive advantage in one (or more) of the businesses in which the corporation operates emerged as decisive in maintaining the support of independent audiences.

$$
\text { attribution irresponsibility legitimacy }
$$

Copyright of Academy of Management Journal is the property of Academy of Management and its content may not be copied or emailed to multiple sites or posted to a listserv without the copyright holder's express written permission. However, users may print, download, or email articles for individual use.
\end{abstract}

